University at Buffalo School of Law

Digital Commons @ University at Buffalo School of Law

Spring 2011

\title{
Pirate Trials, the International Criminal Court and Mob Justice: Reflections on Postcolonial Sovereignty in Kenya
}

\author{
Mateo Taussig-Rubbo \\ University at Buffalo School of Law
}

Follow this and additional works at: https://digitalcommons.law.buffalo.edu/journal_articles

Part of the Comparative and Foreign Law Commons, and the International Law Commons

\section{Recommended Citation \\ Mateo Taussig-Rubbo, Pirate Trials, the International Criminal Court and Mob Justice: Reflections on Postcolonial Sovereignty in Kenya, 2 Human.: Int'l J. Hum. Rts., Humanitarianism, \& Dev. 51 (2011). Available at: https://digitalcommons.law.buffalo.edu/journal_articles/145}

(c) 2011 University of Pennsylvania Press. All rights reserved. Except for brief quotations used for purposes of scholarly citation, none of this work may be reproduced in any form by any means without written permission from the publisher. For information address the University of Pennsylvania Press, 3905 Spruce Street, Philadelphia, Pennsylvania 19104-4112.

\section{IN COPYRIGHT}

This Article is brought to you for free and open access by the Faculty Scholarship at Digital Commons @ University at Buffalo School of Law. It has been accepted for inclusion in Journal Articles by an authorized administrator of Digital Commons @ University at Buffalo School of Law. For more information, please contact lawscholar@buffalo.edu. 


\title{
Pirate Trials, the International Criminal Court, and Mob Justice: Reflections on Postcolonial Sovereignty in Kenya
}

\author{
But jurisdiction is not merely an ambit or sphere (better \\ described in this case as "competence"); it is basically_as is \\ visible from the Latin origin of the word itself, jurisdictio-a \\ legal power, hence necessarily a legitimate power, "to state \\ the law" (dire le droit) within this ambit, in an authoritative and \\ final manner.
}

-Prosecutor v. Tadic

Jurisdiction is typically understood in relation to territory or nationality. ${ }^{2}$ This conceptualization complements a global order of separate sovereign states, each enjoying the power to judge within its territory and to create law for its citizens. Universal jurisdiction, by contrast, entails the ability to judge offenders who have no connection to the state sitting in judgment. Decoupled from territory and nationality, the exercise of universal jurisdiction raises the question of whether it undermines a global order of sovereign states by allowing one state to reach into the affairs of another. This question is underscored by the crimes that, in the twentieth century, were found to give rise to universal jurisdiction, such as crimes against humanity that, in one common formulation, "shock the conscience" of mankind. There is an apparent tension between a global order of state sovereignty and the exercise of universal jurisdiction that either promises to curb sovereign abuses or threatens to conceal imperial meddling behind a judicial façade.

There are, however, other ways in which the relation between state sovereignty and universal jurisdiction might be construed. For instance, the figure of the pirate, the original object of universal jurisdiction, suggests a different relationship. The pirate acts in a zone beyond sovereignty — the high seas — and acts not on a sovereign's behalf. The exercise of universal jurisdiction in prosecuting piracy thus seems to complement a global order of territorial states. The pirate was hostis humani generis, the enemy of all mankind, or at least the enemy of the state system. ${ }^{3}$ Conversely, the perpetrator of crimes against humanity—-the modern enemy of all mankind —often claims to act in the name of the state. Presented thus, we have two distinct conceptions of the relationship between sovereignty and universal jurisdiction.

Over the past few years in Kenya, various stories have unfolded side by side that provide a more nuanced illustration of the ways that sovereignty and universal jurisdiction interact. On the one hand, Kenya has been unable to establish a domestic process to punish the political and business elites said to be behind the vicious ethnic 
violence occasioned by the contested election in 2007. In response, the prosecutor of the International Criminal Court (ICC) has initiated proceedings on his own motion and asserted his intention to prosecute a handful of perpetrators for crimes against humanity. On the other hand, over roughly the same time period, starting in 2006, Kenya has accepted delivery of and begun prosecuting Somali pirates captured by the naval forces of various wealthy states on the high seas, asserting its universal jurisdiction over them. For a moment, then, we have in Kenya both the oldest and one of the newest objects of universal jurisdiction. Even as Kenya imports the original "enemy of all" - the pirate-it prepares to export to The Hague the new "enemy of all" - the perpetrator of crimes against humanity.

How should we understand this conjunction in Kenya? Does the profound tension produced by the dual appearance of figures from such different historical moments constitute a contradiction? Are the two stories expressive of different understandings of sovereignty and global order, or do they fit together as a coherent whole? Is the twentieth-century extension of universal jurisdiction from piracy to crimes against humanity expressive of the roughly contemporaneous decoupling of formal sovereignty from power after World War II and decolonization? Drawing on brief visits to Kenya in 2008, 2009, and 20I0, including firsthand observations of pirate trials in Mombasa, I take up these questions. The abstract problem of the relation between universal jurisdiction and state sovereignty should be localized and theorized, I suggest, in relation to the postcolonial African sovereign state, its relations with more wealthy states, and its relation to its own citizenry.

The importing of pirates and exporting of criminals against humanity are not the only instances in Kenya where we can trace the intermeshing of state sovereignty and universal jurisdiction. Indeed, in order to establish a baseline from which to contemplate the co-presence of the ICC and the pirate trials, we must consider the degree and manner in which the Kenyan state has jurisdiction over Kenya. I attempt to do this through a consideration of a third feature of law and punishment internal to Kenya but external to the Kenyan state: "mob justice," which consists in the beating and occasional killing of accused miscreants by a spontaneously assembled group. Mob justice evokes some of the texture of everyday life in much of Kenya, where state institutions fail to provide security, where individuals feel beset by crime with little police protection, where, in sum, Kenya seems unable to carry out some of its most important domestic sovereignty functions. The claim of the mob to deliver justice, and the notion that everyone is empowered to punish, should, I suggest, be seen as a form of universal jurisdiction enjoyed by the mob over this other "enemy of all."

Each of my three cases illustrates a distinct way in which postcolonial sovereignty is compromised from the vantage point of classical conceptions of state sovereignty. By promoting Kenya as a venue for pirate trials, wealthier states are using its postcolonial jurisdiction to displace their own (arguably nontransferable) obligations to prosecute pirates. At the same time, the postcolonial state is not without some bargaining power-haggling, for instance, over the cost of Kenya's cooperation. In the ICC legal process, we can see another challenge to state sovereignty, one that seems to fall principally on postcolonial—and especially African—states. But formal sovereignty is preserved in both the pirate trials and the ICC, since Kenyan consent is part of both 
cases. Mob justice, however, evokes a state failing in its sovereign domestic obligations. A comparison of these three cases reveals some interesting parallels: like the ICC, mob justice asserts its legitimacy as arising from the failure of the Kenyan state; like mob justice, the pirate trial concerns the right of any actor to punish the "enemy of all."

Rather than catalogue how one state perhaps falls short of an international ideal, my primary interest is in two other themes. The first entails questions about who has jurisdiction - understood in a general sense as the right to speak the law. Each of the three instances entails a creative uncertainty about who is speaking, which I describe, following the suggestion of Joseph Slaughter, as "juris ventriloquism" and throwing the sovereign voice. ${ }^{4}$ In a sense, "ventriloquism" is involved whenever individuals act in some official capacity to enact, interpret, or apply the law. Indeed, persons exercising powers delegated to them are expected not to be speaking for themselves but to be expressing the will of the people, the legislator, reason, god, or some other source of law. Ventriloquism in the cases I discuss stands out because of the uncertainties about who is speaking and about who (or what) is imagined to legitimate that speech. The notions of ventriloquism and throwing the sovereign voice help articulate the question of whether some other state, or even humanity, is speaking through Kenya and the judges in the pirate trials. At the ICC, the prosecutor speaks for humanity and justice, but also, with some license, for the Kenyan state; in this sense, the state might be said to "speak" against itself. In the mob, the sovereign right to punish is decoupled from mediating institutions such as courts and prisons. Mob justice might be read as a claim to enact justice directly, and in this sense the mob purports to be a direct agent of justice, not its institutionally mediated "ventriloquist."

Putting these instances together, we might say that Kenya is performing a ventriloquist role for an international community, in perhaps a worthy undertaking of global cooperation. But when it seems most important for the state to serve as the voice of its citizenry and enforce its laws, Kenya seems to have grave difficulty doing so. Kenyan state officers, we are told, too often, through personal corruption, "speak for themselves" not for the public. In sum, the Kenyan state seems to find it easier to speak for humanity than to speak for Kenyans.

The second theme concerns the relation between law, land, and sea. With respect to the seas, we can discern a "reterritorialization" of the sovereignty-free zone as states seek to extend their control over the high seas with exclusive economic zones, new rules for archipelagic states, longer definitions of territorial waters, and the global reach of the U.S. military. ${ }^{5}$ Going in the other direction, and echoing older European notions of precolonial polities, there is also a process of what we might call the "oceanification" of land, whereby many postcolonial states are treated as sovereignty-less, "ungoverned territories," in language adopted by the U.S. Department of Defense. ${ }^{6}$ Indeed, the sea often seems to be a more governed zone and site of sovereign control than land. These dynamics are at play in Somalia and, in less obvious ways, in Kenya. Can we think of the current conjuncture of events in Kenya as, in somewhat poetic terms, the international law version of global sea level rise, the sovereignty-less sea swallowing up the sovereign on land?? Floating in on that tide, preserving the "sovereignty-free" status of the seas, is the U.S. navy and now, at least off the coast of Somalia, the Chinese navy as well. This theme and the notion of juris ventriloquism 
both draw our attention to shifting relations between jurisdiction and a global spatial order.

\section{Postcolonial Sovereignty}

One of the hallmarks of political modernity is the relocation of political sovereignty from the divine authority of God and King to the secular realm of the People. In an essay on the arrest of Augusto Pinochet, Paul Kahn articulates this conception of sovereignty in the context of universal jurisdiction: "In a democratic regime in particular, sovereignty and law are tightly linked: the sovereign people govern through the rule of law; and by following the law, citizens participate in popular sovereignty and achieve self-government." 8 Such notions of popular, "internal" sovereignty presuppose, however, that a political community has meaningful autonomy independent of an international order of states.

By contrast, colonialism officially dictated a conception of sovereignty as external, as something — a gift or imposition—from abroad. The decades following World War II ushered in a transformation from a regime of formal inequality between European sovereigns and various others-colonies, trusteeships, etc.- to an emergent postwar United Nations order of formal sovereign equality. ${ }^{9}$ Decolonization was by no means the simple extension of Westphalian sovereignty to previously colonized peoples. Through independence and decolonization, postcolonial states assumed sovereign status and affirmed the notion that sovereignty comes from within, from their people. From this perspective the process of decolonization entails the transformation of externally dependent sovereignty into an "internal" conception of independent state sovereignty. In practice, however, the political experience of decolonization left most postcolonial states, including Kenya, in a situation of only partially realized internalization of sovereignty. ${ }^{10}$ Thus, we are often told that new states such as Kenya are not really made of a "people" but rather are made of diverse peoples lumped together for the colonists' convenience; that the new states have remained colonialist in some respect and do not act in the interests of their populations; that, despite decolonization, rich states continue to exploit former colonies, and thus the new states are not sovereign in any meaningful sense; that the new states are funded by foreign sources, and thus are really vehicles for outside interests. ${ }^{11}$ In sum, because decolonization did not entail a transformation in the global distribution of political and economic power, formal legal sovereignty masks an ongoing inability to create an autonomous political order.

In Robert Jackson's study of the decoupling of legal form from political reality, the postcolonial state is a "quasi-state" — an entity enjoying the legal trappings of sovereignty secured by the international order but not possessing the empirical features of sovereignty, such as genuine political power, the ability to govern or to defend itself. Internationally, the new sovereigns enjoy "negative" and juridical sovereignty, not "positive" and actual sovereignty. ${ }^{12}$ Sovereignty in the postcolony remains a kind of gift bestowed from above, that is, from the metropole. An alternative, more economically oriented argument is that the postcolonial state is essentially a victim of new forms of neocolonial extraction, or that structural adjustment and aid have emerged as indirect ways for metropolitan powers to govern former colonial, now 
nominally sovereign spaces. Yet both the "gift" and neocolonial "larceny" views concur in suggesting that the legal order of formally sovereign postcolonial states-on the domestic and international levels - is not descriptive of actual practices and a lived order of compromised postcolonial sovereignty.

This decoupling of legal sovereignty from a lived political order in the postcolony is also the moment of the rise of the UN, the United States and the USSR, and the Cold War. The same era also saw the rise of "humanity" as a presence beyond the immanent order of the state in international law and relations. According to one international tribunal, the Universal Declaration of Human Rights (1948) initiated a process by which a "State-sovereignty-oriented approach has been gradually supplanted by a human-being-oriented approach."13 The rise of the human being and the demise of the sovereign state in international affairs are certainly overstated, but it seems important to consider how these developments operate together. In the conjunction of current international events in Kenya, we see various symptoms of the transformation that turned the formerly colonized state into a formally sovereign state, as well as various processes that are currently redefining the notion of sovereignty.

\section{Pirate Trials}

In the early modern period, piracy was in many cases a state-sponsored affair. In their struggle against Iberian supremacy and its assertion of trade monopoly in the Americas and the East, for example, the British and the Dutch made common use of pirates. ${ }^{14}$ When operating with a license from a sovereign, pirates were, at least according to that sovereign, not pirates but privateers. ${ }^{15}$ Piracy also referred to non-European "indigenous" coastal communities who resisted the European imposition of trade monopoly in their waters. ${ }^{16}$ Likewise, the Barbary "pirates," whom the United States confronted shortly after independence, acted on behalf of various Muslim North African cities and hence could be thought of as corsairs or privateers. ${ }^{17}$ Additionally, the British captured slave traders and tried them for piracy, asserting that this could be done under the "law of nations." (This innovation was also disputed: slavers, after all, had long been integral parts of the global system. ${ }^{18}$ ) One thing we see, then, is that piracy was part of the struggle to define a global order, a working out of whose violence is that of a sovereign, and whose is piratical and private.

While sponsoring pirates was expedient to a weak and developing English state that lacked the funds to pay up-front for a large navy, the consolidation of British sea power obviated the need to sponsor such characters. With the transformation of the British military into a formal not-for-profit public service entity, the function and violence of privateers was brought "in-house," under direct control of the modern state. ${ }^{19}$ Thus, modern-state navies were tasked with eradicating piracy. The historian Marcus Rediker describes the British-led campaign to eradicate piracy in the eighteenth century as an "international campaign of terror." ${ }^{20}$ In London, New York, Boston, Port Royal, Providence, Cape Coast Castle, and Salvador "authorities staged spectacular executions of those who had committed sea banditry." Arriving in port, one would see the "gibbeted corpse of one who had sailed under the black flag, flesh rotting, crows picking at the bones." By the early nineteenth century, piracy had been largely suppressed. 
The current outbreak of piracy around the Horn of Africa provokes a reconsideration of the modernist narrative of the consolidation of the state's monopoly on violence, and it has met a different response from the one recounted by Rediker. ${ }^{21}$ The collapse of the Cold War-financed Somali military state in I99I is a central factor in the rise of piracy in the area. Although Somalia is now the archetype of a "failed" state, the origins of piracy there are often traced to the practice of repelling foreign fishing vessels from Somali waters and, perhaps paradoxically, to the practice of selling licenses - often on old government letterhead — to foreign vessels for access to Somali waters. ${ }^{22}$ Piracy has evolved into a far-reaching enterprise, with support sometimes provided by the Somali diaspora and a "business model" in which pirates receive payment based on different kinds of "shares." 23 A document recovered from one "company" of pirates describes a new "merit-based reward" of U.S. \$2,000: "The company will continue its reward system and it is open to all. As the saying goes 'the parents initially love their children equally but it is the children who make them love some more than the others'. So does the company. It is up to your abilities to qualify this easy-to-earn reward $[$ sic $] .{ }^{24}$ At the time of writing, there are about twenty vessels being held in Somalia, and the price of ransom is typically in the U.S. \$I-2 million range. ${ }^{25}$ Thus, this is neither snatch-and-grab piracy common in the Malacca straits, nor capture for resale or personal use. As a matter of everyday practice, deals with Somali pirates are often carried out in a business-like manner.

The collapse of the Somali state has given rise to three more or less distinct regions, each with different connections to piracy. Somaliland, in the northwest, is relatively stable, holds elections, and is said to be helping with counterpiracy efforts and to be eager to conduct pirate trials in its own courts. ${ }^{26}$ Somaliland has declared itself independent, but has not been internationally recognized as a sovereign and clearly hopes that its cooperation will bolster claims for international recognition. ${ }^{27}$ Puntland, on the Horn, has been accused of supporting piracy. ${ }^{28}$ To the south, the severe law-andorder government of the Union of Islamic Courts suppressed piracy, but this group's overthrow by the United States and Ethiopia in 2006 led to an increase in piracy. It also led to the rise of Harakat al-Shabaab al-Mujahideen (commonly known as alShabaab, "the Youth"). ${ }^{29}$ There is speculation that al-Shabaab profits from piracy, but a UN monitor states that there is "no evidence" of "structured cooperation" between the group and pirates, ${ }^{30}$ and al-Shabaab has sometimes attacked pirates for interfering with trade from the ports it controls. ${ }^{31}$ With the collapse of central state power, there is no internationally recognized Somali sovereign with the capacity to license or authorize the pirates, much less to transform their private violence into the public violence of the privateer or the navy_as, for instance, the English did in the eighteenth century.

In response to this growth in Somali piracy, an international naval flotilla has congregated off East Africa-including French, U.S., Russian, Indian, and British warships. Dealing with pirates is also serving as a coming out party for the navies of newly prominent states: for the first time since the fifteenth century, Chinese naval vessels were seen outside of East Asia. In addition, the UN Security Council has passed a number of resolutions (under Chapter VII) that might be read as redefining Somali sovereignty in that they allow other states to pursue pirates not only in international 
waters but into Somali waters as well, something that clearly worries other states with piracy problems, such as Indonesia. ${ }^{32}$ Those resolutions contemplate that the fight against piracy will be conducted not only on the high seas but "in" Somalia-that is, in its territorial sea and on its land. Although the resolutions require the formal consent of Somalia, the Somali government (the Transitional Federal Government) is itself largely the creation of the international community and its writ within Somalia barely extends outside the presidential compound in Mogadishu. ${ }^{33}$ In this arrangement, we see the two themes I wish to highlight: juris ventriloquism, whereby powerful states seem to speak through a lesser "sovereign," and the oceanification of land, whereby the sovereignty of land is no longer counterpoised to the sovereigntyfree high seas; rather, like the sea, land becomes an "open" space.

The intersection of trends in the shipping industry and the distribution of naval power helps to explain why conventional forms of jurisdiction are not available. Commercial ships must be registered with and fly the flag of a state. On board, the law of that state applies, and the state exercises jurisdiction over the ship for various purposes. But ships need not fly the flag of their true owner or crew; they may, in essence, have their own "nationality." ${ }^{34}$ About half of merchant ships fly so-called flags of convenience, typically Panama, Liberia, or the Bahamas, states that have more lenient requirements with regard to labor and safety regulations and hence lower costs. ${ }^{35}$ In addition, crews are often from non-Western and poorer countries, such as the Philippines. This migration of crew and ship nationality toward marginal and poorer states, and the fact that naval power is the possession of more wealthy states, increases the likelihood that the naval forces capturing pirates will not have nationality jurisdiction. When there is a mismatch between the nationalities of the pirate capturer and victim, the capturing country may employ universal jurisdiction.

These distributions of merchant vessel nationality and naval power have produced practical legal issues for navies patrolling the Horn, specifically with respect to what to do with pirates they capture. The absence of a functioning government in Somalia to which to send the pirates has precluded relying on the Somalis to mete out justice themselves. Some countries have brought pirates home for trial, but capturing states have been hesitant to exercise universal jurisdiction, perhaps unwilling to pay for an exercise in universal jurisdiction on behalf of, say, a Panamanian vessel with a Korean crew. Universal jurisdiction in this context might appear more like a burden, a kind of self-sacrifice for a global public good. Many have also expressed concern that Somalis could qualify for refugee status and that it would be impossible to deport them because of obligations against refoulement. ${ }^{36}$ Indeed, the lack of a forceful response to pirates is interpreted by many as indicative of how international law, and postwar human rights commitments in particular, have constrained the once proud sovereign state. The status of pirates in the early modern era is a complex topic, but in many formulations they were distinct from criminals and from enemies. ${ }^{37}$ If pirates were once those who could be treated like "Beasts of Prey," 38 subject to summary justice, current practice seems to struggle with their status. The supposed "enemy of all" turns out to be the bearer of rights. As Douglas Guilfoyle and Andrew Murdoch write: "Despite some classical writers' rhetoric suggesting that pirates are at war with all humankind, we cannot assume we are at war with pirates." ${ }^{39}$ And while there has 
been discussion of creating an international court for piracy, or extending the jurisdiction of the ICC to include piracy, ${ }^{40}$ in the absence of such an institutional solution, many states have preferred simply to let captured pirates go-a practice disparaged as "catch and release." 41 Some of these attitudes may be discerned in U.S. conduct: the United States indicted in federal district court the one surviving pirate who attacked a U.S. flagship, the Maersk-Alabama, and, more recently, eleven pirates who attacked, remarkably enough, U.S. naval vessels. But when the United States had universal jurisdiction, as with pirates it detained aboard an Indian vessel it recovered in 2006, it chose a novel route: it sent the pirates to Kenya.

\section{The Kenyan Solution: Offshoring International Justice}

Indeed, other than those who get released, most of the pirates recently captured off the Horn of Africa have been delivered to Kenya — about $\mathrm{I} 2 \mathrm{O}$ as of this writing — and Kenya has begun pirate trials in the port city of Mombasa. ${ }^{42}$ With this innovation, it would appear that the emergent international response to resurgent piracy is not to reinstitute a theater of legal terror in the mode of the eighteenth-century British campaigns but rather to promote a different (and admittedly less dramatic) legal innovation centered on the transfer of pirates from one sovereign to another. At the same time, the powerful states' reluctance to try pirates themselves, and the policy of transferring pirates to a third country or simply letting them go, suggests that all may not be quite so tidy in the house of international law.

At first blush, Kenya's ability to prosecute the Somali pirates even where there is no connection to Kenya is typically explained as an exercise of universal jurisdiction - and by occasional invocations of the phrase that piracy is a "crime against mankind." 43 Piracy, according to the UN Convention on the Law of the Sea (UNCLOS) (1982), more or less reflected in Kenyan criminal law, consists in "any illegal acts of violence, detention or any act of depredation," on the "high seas," "outside the jurisdiction of any State" and "committed for private ends." 44 In an appellate decision affirming jurisdiction over the group of Somalis delivered by the United States in 2006, the High Court of Kenya at Mombasa opined that even if Kenya had not ratified UNCLOS and had not provided for punishment of piracy in its criminal law, the lower court was "bound to apply international norms and Instruments since Kenya is a member of the civilized world and not expected to act in contradiction to expectations of member states of the United Nations." 45 Yet this was the same jurisdiction that other states had just declined to exercise, and the Court did not address the question of whether Kenya was empowered not only to prosecute but to receive the pirates. There is some doubt-although not one I heard raised in court nor in the single appellate opinion issued thus far-about whether UNCLOS permits the transfers. Article IOS of the Convention provides that "courts of the State which carried out the seizure" may determine punishment—more pointedly, by encouraging international cooperation, the Security Council resolutions seem, at least in principle, to endorse the transfer idea. ${ }^{46}$ All of the coastal states-Kenya, Somalia, Djibouti-lack warships to catch pirates themselves, but, as one UN representative diplomatically framed it, "Some countries provide a navy, others can help with prose- 
cution." ${ }^{47}$ Universal jurisdiction allows everyone to "help," even if they don't have any naval "assets."

Some of the arrested Somalis have objected that Kenya has no business trying them, mere fisherman who never harmed Kenya. In court I also observed Kenyan prosecutors assert that their jurisdiction is based on various secret and public Memoranda of Understanding (MOU) that Kenya has signed. ${ }^{48}$ The use of an MOU, instead of a treaty or other more formal instrument, allows executive branch officials to act with less oversight, especially when the MOU is secret. In this sense, it is one small part of a struggle over sovereignty within a constitutional order. The U.S. MOU provides that it is not a "binding international agreement," which suggests that while one objective is to deliver the pirates to (Kenyan) justice, another is to ensure that neither party may seek to enforce the MOU's terms in court. We might, then, read the use of MOUs as indicative of the separateness of the parties and of their desire to preserve their freedom of action. But the opposite reading seems plausible: that the informality of the process and the use of MOUs indicate just how intimate the parties are. Neither the Kenyan ambassador to the United States nor a U.S. embassy official in Nairobi offered an explanation about why the MOU should be secret, although the latter hinted that it was at the behest of Kenya.

The MOU agreements that I have seen do not purport to confer jurisdiction to the Kenyan courts, but the notion that they could is interesting. Could Kenya be exercising jurisdiction transferred from the United States, delegated by a secret agreement, in addition to or instead of its own free-standing universal jurisdiction? Even if implausible, this sense of transferable jurisdiction captures an important feature of the overall program, raising the question of whether Kenya is acting as a sovereign, or on behalf of one; whether we are studying separate sovereigns, or, rather, entities nested one within the other. It nicely evokes the uncertainties of juris ventriloquism - are Kenyan courts speaking the law on behalf of Kenya, the United States (or other "donor" nations), the UN Security Council, humanity, or perhaps all of these at once? The pirate-trial program is not simply an instance of one sovereign acting against the pirate; rather, a group of sovereigns is acting together, with universal jurisdiction apparently facilitating their coordination. The MOUs describe and formalize the processes entailed in the hand-off, while universal jurisdiction allows Kenya to judge the pirate.

Earlier, I speculated that, with respect to piracy, universal jurisdiction and state sovereignty could be mutually supportive. That speculation seemed plausible because in acting against the pirate a state would not—given the UNCLOS definition of piracy as being for "private" ends-intrude on the interests of other sovereigns. But with the transfer program, that is not quite the full story, for Kenya is acting as part of an order where some kinds of tasks — trying pirates — are apparently better left to some sovereigns than others. Thus, while the initial conception left the "sovereign equality" described in the UN Charter undisturbed, ${ }^{49}$ the transfer program at least raises an interesting question about a global division of adjudicatory labor, if not about more substantial inequality. While postcolonial specialization is typically associated with the provision of migrant labor and the extraction of raw materials, in this instance what Kenya is selling is access to its jurisdiction. 
While this arrangement might seem to be an arm's length transaction that serves formally to enhance Kenya's sovereign standing and international prestige, it turns out that the bill of sale has come with a series of strings attached that may result in precisely the opposite effect. Despite the transfer to Kenya, the various wealthy donor states have not simply washed their hands of the pirates but rather have used the pirate trials as an occasion to give Kenyan prisons and courts a close look. A group of international lawyers from Paris, Lawyers of the World, came to Mombasa to help defend the pirates and condemned the transfer program for depriving the pirates of their rights. ${ }^{50}$ The theater of Kenyan law started to look like one in which the Kenyan courts, as much as the pirates, were on trial. Instead of being treated as a "hero" of the international community, as one Kenyan prosecutor said should be happening at a training session I attended in 2009, Kenya has been informed that its prisons and courts are perhaps not good enough—even for Somalis. Were the pirates now vehicles for international standards, standards that Kenya, as is often said, does not meet in the treatment of its own citizens? Instead of a dumping program, was this to be a program to elevate Kenya to world standards? ${ }^{51}$

While Kenya clearly wanted financial support in exchange for undertaking the pirate trials, the donor states have insisted on monitoring such assistance closely, concerned about corruption. One consultant working in Mombasa spoke to me of Kenyan officials as "children seeking candy." A representative of a naval mission described how annoyed the local detectives were that he would not buy them a new vehicle but rather was planning to provide a maintenance contract with a local mechanic to fix the many broken-down vehicles in their lot. A U.S. embassy official, while offering training on how to organize a litigation file, promised to personally deliver paper and a file cabinet. I asked a Kenyan prosecutor why cash could not be sent to Mombasa instead of driving reams of paper from Nairobi, and he said that the foreign states did not trust the Kenyans. Before signing an MOU agreement with the EU, Kenya is said to have "presented a I2-page wish-list of expensive items and money for retreats." It was not only the Kenyans who looked a bit awkward: "One of the officials described diplomats running around Nairobi buying up color printers." 52 Donor states thus transfer pirates to Kenya yet seem unable to let them go, concerned about Kenyan standards and equipment. And the Kenyans, understandably, are unwilling to let the foreign donors depart without offering some aid. That these awkward transactions are ambivalently situated as benevolent gifts, reciprocal exchanges, or unseemly transfers nicely articulates the complexity and variability of the bonds between Kenya and the donors. In particular, these transactional ambivalences articulate the question of whether these are bonds between sovereign equals or patron and client.

The exercise of universal jurisdiction can be read as an altruistic act-why, after all, should a state expend its resources prosecuting individuals who have no nexus to it? But the pirate transfers and trials have been subject in Kenya to a variety of readings: that Kenya is sacrificing itself as a hero for the international community; that it is being exploited as a dumping ground by wealthy states; that it negotiated a good deal for itself and is exploiting states too inhibited to kill pirates and too indifferent to try them. Reflecting the instability of these readings, Kenyan officials began 
to rethink the deals they had struck. The media speculated that Kenya had been "coerced" and, in the words of a government minister, "short-changed." 53 Speaking in April 2oro, Kenyan Attorney General Wako announced the end of the pirate program. He described an "inherent contradiction" in the use of Kenya to try pirates, saying of the foreign nations that "they keep on rubbishing our judicial system ... Why then are these countries afraid to prosecute the pirates, arrested by their naval forces in the high seas?" ${ }^{4} 4 \mathrm{He}$ continued: "As soon as they give us the pirates, they dump them here and forget about what happened." Instead of leading an international charge against the enemy of all, Kenya found itself, as the attorney general put it, "stand[ing] alone." 55 Kenya's withdrawal prompted more talk of an international tribunal, and there are some signs that capturing states are again thinking about trying pirates at home. Kenya's announcement came within days of the decision of the International Criminal Court to permit the ICC prosecutor to proceed with an investigation in Kenya. One rumor claimed that the attorney general himself was on the list of possible perpetrators. ${ }^{56}$ But a month later, in June 20Io, Kenya announced that it was back in the pirate trial business - the EU had pledged more funding and paid for a new courtroom at the prison where the pirates were being held outside Mombasa. ${ }^{57}$

Kenya has imported a struggle over the pirate previously internal to the capturing states - the struggle over whether the pirate is really no longer the enemy of all, whether he truly had been assimilated to the twentieth century's regime of rights. In this affair, we see states struggling with that transformation in public law. I believe we can interpret the pirate-transfer program as an attempt to displace the tension that such transformation creates: questions about who speaks the law and on whose behalf. This tension was exported to Kenya along with the pirates, which is hardly the deal, one suspects, that Kenya had in mind.

\section{The International Criminal Court}

The judges decided. There will be justice in Kenya. To contribute to the prevention of crimes during the next election we must proceed promptly. -ICC Prosecutor Luis Moreno-Ocampo ${ }^{58}$

While Kenya was busy importing apparently impoverished Somali pirates, it seemed likely to begin exporting to the Hague well-to-do perpetrators of crimes against humanity. In the December 2007 election, Kenya seemed set for a peaceful transition. 59 The opposition party was leading the vote count by a large margin. But at the last minute, the incumbent was declared the winner and hastily sworn in. Ethnically organized violence broke out as opposition party supporters attacked those of the incumbent, which was followed by reprisals. Over one thousand people were killed, widespread sexual assaults took place, and hundreds of thousands were displaced from their homes. Some commentators saw genocide looming, while Kenya's main donor states applied increasing pressure on the country's leadership. Former UN secretary general Kofi Annan negotiated a deal in February 2008 in which there would be a coalition government: the incumbent would be president and the opponent would fill the newly created post of prime minister. A new constitution would be drafted. But would those who instigated and led the violence be punished? On this question, the 
Kenyan political class has been unable to establish a way forward. The ICC is poised to prosecute a few of the key perpetrators for crimes against humanity.

Individual states can act against perpetrators of crimes against humanity under universal jurisdiction. The UN Security Council has also created courts to prosecute offenses against humanity in Rwanda and the former Yugoslavia, among other cases. The ICC offers another mechanism for representing and defending the interests of injured humanity. It has, under the Rome Statute, independent international legal personality, and thus, technically, it is not simply a creature of the UN or the state system. States "accept" the ICC's jurisdiction over crimes of universal jurisdiction by becoming a party to the statute, which limits the Court's jurisdiction to "the most serious crimes of concern to the international community as a whole": genocide, crimes against humanity, war crimes, and the crime of aggression-not, we might note, piracy or stealing an election. ${ }^{60}$ Simultaneously authorized by states and yet reaching beyond them to universal values, the ICC answers the question of who is authorized to act in the interests of "justice" on behalf of humanity.

The conjunction of pirate trials and ICC prosecutions in Kenya also presents an opportunity to reflect on the historical evolution of universal jurisdiction. Eugene Kontorovich has argued that the post-World War II extension of universal jurisdiction over war crimes and crimes against humanity was built off of the universal jurisdiction applied to piracy, all of them connected by their alleged "heinousness." ${ }^{61}$ But Kontorovich also notes that, historically, piratical acts were not always seen as especially heinous and indeed were often sponsored by states. Thus piracy, he concludes, is a "hollow foundation" for more recent versions of universal jurisdiction. Yet heinousness, as Kontorovich also recognizes, is not the only way to conceive the link between old and new. For instance, as another author notes, there are arguments about practical matters of administration: on the high seas and during war, there is often a "lack of any adequate judicial system operating on the spot where the crime takes place-in the case of piracy it is because the acts are on the high seas and in the case of war crimes because of a chaotic condition or irresponsible leadership in time of war." ${ }^{62}$ Even so, universal jurisdiction with respect to piracy seems a clear expression of an international order based on state sovereignty over territory; the enemy of all is outside the state. The ICC's version of universal jurisdiction, by contrast, seems to be about finding the enemy of all at the heart of the state. Thus we may wish to concur with Kontorovich in seeing a disjuncture between old and new, between the prosecutions of the pirate and the perpetrator of crimes against humanity. One amplifies the voice of state sovereignty; the other seems to mute it. Yet this narrative of disjuncture does not confront the features of postcolonial sovereignty discussed earlier-namely, the decoupling of legal sovereignty from power. The co-location of the pirate trials and the ICC in Kenya encapsulates the position of the postcolonial state, and the various ways in which such states do not enjoy what we classically think of as sovereignty. In other words, to see the ICC as undercutting state sovereignty presumes a conception of sovereignty that may not be applicable to many states.

But is Kenya really being denied its ability to engage in an act of sovereign selfcreation and self-governance by the ICC? It had ratified the ICC Treaty in 2005 but failed to pass implementing legislation before the 2007 elections. The government's 
initial efforts to punish offenders were rejected by Parliament in February 2009, which prompted the Commission of Inquiry - a body established after the violence- to transmit names of possible perpetrators of crimes against humanity to the ICC in July 2009. Meeting with the ICC prosecutor, an official Kenyan delegation agreed that within twelve months Kenya would either establish some form of accountability or refer the matter to the ICC. Some weeks later, the government announced a plan that didn't involve sending the matter to the ICC. ${ }^{63}$ Kenya had declined, we might say, to throw its voice to the prosecutor, and for the first time, the prosecutor sought to bring a case without a referral from a state or the Security Council. In relying on Kenya's earlier consent to the statute, the prosecutor had appropriated the Kenyan state's voice, while at the same time speaking in the voice of aggrieved humanity. In a sense, therefore, the ICC prosecutor is both outside and inside Kenyan state government. ${ }^{64}$

We might speculate that the Kenyan political classes are relying on the ICC to act. Were this the case, Kenya might appear to have abdicated self-government, and therefore sovereignty in a robust sense. The Kenyan president and cabinet contemplated withdrawal from the ICC but backed away, perhaps because some donor support is tied to ICC membership. ${ }^{65}$ Is Kenya speaking through the ICC? Or is it, most crudely, donor states that are speaking the law by insisting on Kenya's continued participation with the ICC? A case could be made for each-and that is the point; the international system provides a structure where it is not always clear who is speaking on behalf of whom. The ambiguities of the relationship between Kenya and the ICC require us to reframe the questions about possible conflicts between state sovereignty and universal jurisdiction. If Kenyan sovereignty does not live up to an idealized conception of sovereignty as a kind of autonomous self-creation (in either the pirate trials or ICC prosecutions), neither does Kenya appear only as a mere appendage or colony of larger imperial states and global structures.

\section{Mob Justice}

Justice became an item for sale leaving it inaccessible to a majority of poor Kenyans. One consequence of the many years of corruption was the increasing resort by many Kenyans to what has been popularly called "mob justice" - that is lynchings of criminal suspects.

—Mutuma Ruteere (writing about President Daniel arap Moi's years in office) ${ }^{66}$

My two stories about universal jurisdiction draw attention to external actors and donors, even as they problematize who is "outside" the Kenyan state and in what sense we should think of the state as sovereign. Both stories concerned, in part, the shortcomings of the Kenyan justice system. Apparently it is unable to bring to justice the planners of the postelection violence, and the pirate trials generated concern about Kenya's ability to handle those cases. But what about more everyday offenses? How does the tension between sovereignty and universal jurisdiction manifest itself in the internal relations between state and population? Many commentators suggest that the Kenyan courts and police do not provide basic security and that-like the payment for pirate trials-financial bargaining for justice takes place between the state and its own citizens. Those who cannot pay, says Mutuma Ruteere in my epigraph, have 
sometimes resorted to a form of self-help: mob justice. Mob justice describes a form of action in which citizens spontaneously form groups and publicly, under a claim of justice, take (sometimes lethal) punishment into their own hands. Most simply, it raises the question of whether and in what sense the Kenyan state has jurisdiction over Kenya, and whether in mob justice we see another kind "universal jurisdiction," whereby ordinary people are empowered to act. It suggests another instance of the mobility of the sovereign voice and its ability to speak the law, as citizens take up some of the core sovereign decisions over punishment and over life and death. While I am not able to do justice to the complex topic of mob justice, in this section I discuss it to contextualize the analysis of the pirate trials and the ICC.

In Kenya, what is called (in English) "mob justice" is a socially recognized form of action. It is widely explained, by scholars and participants, as a response to state incapacity to provide law and order:

The average period of a case in Kenya is $4-5$ years. This has led to lack of confidence in the judicial machinery, with people often giving up their rights after weighing the time and money costs of the whole process. It has also led to the development of some alternative undesirable extra-legal phenomena that is [sic] antithetical to the rule of law such as "mob-justice," where communities seek justice for themselves by communally executing suspects on the spot. This has been attributed to repeated failure of system $[s i c]$ to work with the result of criminals finding their way back to the streets and communities shortly after arrest. ${ }^{67}$

Writing about vigilantism in Kenya more generally, David Anderson describes it as a response to steeply rising crime rates since the I980s, "rapid growth in the urban population, ... . acute housing shortages, declining economic prosperity, rising urban unemployment and the collapse of many institutions of municipal government."68

Mob justice raises a fundamental question about jurisdiction-who is it that really speaks the law in Kenya? On the streets of Nairobi, is it petty criminals, gangs, or the "mob"? But the matter is more complex; there are a range of other actors in Kenya who rely on the failure of the state, even some who are themselves state officials. "The justification is often given," writes Philip Alston, UN special rapporteur on extrajudicial executions, that "the failures of the justice system leave the police with no alternative but to administer 'justice' directly by executing those who they 'know' to be guilty and who, if arrested, would either never be prosecuted or, if charged, would be acquitted." ${ }_{99}$ The same claim is made for the gangs such as the Mungiki that are now hunted by the police but were previously deployed by politicians. ${ }^{70}$ In mob justice we encounter a fragment, although perhaps the least institutionalized, of a larger constellation of nonstate violence-and, more to the point, violence that blurs the lines between state and nonstate action.

\section{Between the Mob and the ICC}

And if any one in the state of nature may punish another for any evil he has done, every one may do so: for in that state of perfect equality, where naturally there is no superiority or jurisdiction of one over another, what any may do in prosecution of that law, every one must needs have a right to do.

-John Locke, Two Treatises of Government ${ }^{71}$ 
The degree to which the postelection violence was organized by the state or other organizations is an important issue in the ICC's claim that crimes against humanity occurred in Kenya. Violence became central to the electoral process as soon as Kenya agreed-under pressure from donors-to hold multiparty elections in I992. Adam Ashforth writes that President Daniel Arap Moi “organized squads of young men to attack Kikuyu residents in the Rift Valley . . . to drive out potential opposition voters and intimidate those who remained ... Moi won himself ten more years as president by means of 'clashes' such as these (though he also bribed voters and officials, repressed dissenters, and rigged his way through elections). At each election since $1992 \ldots$ ethnic clashes have occurred in the Rift Valley." 72 What distinguished the postelection violence of 2007-8, in Ashforth's estimation, was that it was deployed not only to win the election but also to reshape national space, to create ethnically cleansed regions. ${ }^{73}$ One of the questions raised by mob justice-and the other deployments of extralegal violence by the police, gangs, and parties in the electoral cycle-is whether it is accurate (or relevant) to see these acts of violence as expressing the failure of the Kenyan state to achieve a monopoly over violence in its territory. Many of those actors are not simply criminals enjoying impunity; some assert a link to state authority-like pirates of an earlier era licensed as privateers. The blurriness seems relevant here, because some of them-according to the ICC—are running the government.

The ICC Pre-Trial Chamber faced the issue, to put it too crudely, of whether the violence was that of the state or the mob-whether the mob was being used as the vehicle through which elites were speaking or whether ordinary people were in fact leading the elites. In other words, was the violence a result of a "State or organizational policy," as the ICC Statute requires to assume jurisdiction? ${ }^{74}$ In his dissent, Judge Kaul wrote that the "overall picture is characterized by chaos, anarchy, a collapse of State authority in most parts of the country and almost total failure of law enforcement agencies." 75 There was not "an 'organization' meeting the prerequisites of structure, membership, duration and means to attack the civilian population." ${ }^{\prime 76}$ The Kenya National Commission on Human Rights expressed a similar opinion. ${ }^{77}$ The judges in the majority, by contrast, approved the prosecutors' request to proceed with an investigation of Kenya absent a referral from the state on the determination that a "number of the attacks were planned, directed or organized by various groups including local leaders, businessmen and politicians associated with the two leading political parties, as well as by members of the police force."78 The violence was organized, but it is not clear that even the majority thinks there was a "State or organizational policy" behind it; there seems to be something comforting in the view that there is someone in charge who can be held accountable—some "organization" (or the state) that used a broader public as a vehicle for its "policy."

I suspect that we must take the term justice as seriously as the term mob. David Luban argues that since it is human beings, not states, who are offended by crimes against humanity, we should recognize a "vigilante jurisdiction" over the offender, which "carries the implication that criminals against humanity are anyone's fair target." 79 Fearing "lynch-mob justice," however, Luban would delegate this jurisdiction to national or international tribunals. ${ }^{80}$ The crimes the Kenyan mob punishes, often larceny, are not crimes against humanity in the ICC's sense. But the absence of 
protection against crime in general does generate a context where the offended party is a broader community, which, like Luban's humanity, is not represented by an institution. The Kenyan courts apparently do not speak for the injured community. Does the mob pick up where the state leaves off? Is this form of violence direct, nondelegated action?

The conditions that make the mob possible are the weakness and illegality of the state combined with its continued presence. The state fails to act as classic sovereign; but it continues to occupy that space. The potential symmetry between the mob (bringing accountability to the petty criminal) and the ICC (bringing accountability to the elite perpetrator) rests on the inability of the Kenyan state to provide those two forms of accountability. Both purport to be against impunity and to advance justice. The ICC seems set to pursue elite actors within Kenya; the mob pursues the nonelite on the streets. That there is a vigilante group called "the Hague" suggests that the symmetry between the ICC and popular justice is appreciated by some actors in Kenya. ${ }^{81}$

Perhaps it is the victim of mob justice who is the "enemy of all," the one who is beyond the law of the state and is, therefore, subject to some other form of justice. Mob justice reproduces the structural relation of all against one that we see asserted with respect to pirates under the state system. And perhaps the law of the sea, articulating as it does the sovereignty-free high seas, is suggestive for thinking about security and justice on land in postcolonial states, where the sovereign interior has various oceanic, sovereignty-free aspects. Indeed, mob justice challenges the dichotomy between the sovereign land and the sovereignty-free sea. A more empirically accurate conceptualization of both land and sea might be-as Lauren Benton says of the geography of empire-that there are pathways, "corridors" and moments of sovereignty. ${ }^{82}$

\section{Conclusion: Postcolonial Piracy}

Considered together, the pirate trials, the ICC's investigations, and mob violence in Kenya help to illuminate the fraught nature of postcolonial sovereignty. It is hard to imagine a greater gulf than that between the Somali pirate and those likely to be in the ICC's cross-hairs. The pirates are nonelite foot soldiers; the ICC's suspects important public figures. We might take the simultaneous appearance of our two stories to signify that the oldest and newest conception of universal jurisdiction can co-exist, and that pirate and tyrant have finally been recognized as the "enemies of all," properly punished for their heinous acts. By contrast, perhaps the common thread of universal jurisdiction tracks major transformations, inversions even, in our ideas of universal jurisdiction, our global spatial order and the meaning of sovereignty. Indeed, Kenya's tentative decision to withdraw from the piracy program, as the ICC moved forward, underscored the political tension between the two usages of universal jurisdiction in the same political space - that is, that the international community could not count on the Kenyan government simultaneously to cooperate on piracy while at the same time allowing some of its own members to be subject to the ICC. And yet, when provided with additional financial support, the Kenyan courts went back to work on the pirate cases in support of the international order.

To properly evaluate the changes in universal jurisdiction from piracy to crimes 
against humanity, those changes must themselves be mapped onto the roughly contemporaneous transformations in the meaning of sovereignty after World War II and decolonization. This implies a continuity with colonialism: just as the colonial power could exercise jurisdiction over subjects, the newer universal jurisdiction preserves that possibility - at least for the ICC. Thus the old and new may fit together, but in a complex way. We might then see the stories from Kenya as a pithy articulation of the position that postcolonial states occupy-useful to wealthy states as a place to dump pirates, a sovereign who can loan out its "sovereign" powers for a fee, while, with respect to matters of higher politics, subject to the oversight of ICC. Both forms of jurisdiction can be understood as dedicated to preserving the international order. It is just that the role of sovereignty in the international order has changed-from a global regime where sovereignty and power were tightly linked, to one where the mere status of sovereign may tell us very little about a polity.

But the analogy to colonial structures is, I suspect, too easy, offering a perverse comfort in thinking that nothing has changed, that there is an order-however offensive. Are we certain that the boundaries of the "Kenyan" sovereign should or do not include the ICC prosecutor and those other agents of justice, the mob? And when we look at the other actors, such as the states dropping off the pirates, how are we to see their "sovereignty"? They too seem bound to law, simply seeking an easy route to compliance, and this undercuts any simple neocolonial reading.

\section{NOTES}

I am grateful to the Baldy Center for Law and Social Policy for funding for this research. For their comments on this essay, I wish to thank Guyora Binder, John Comaroff, Jim Gardner, Paul Goldsmith, Jennifer Gaynor, Paul Kahn, Fred Konefsky, Makau wa Mutua, Jack Schlegel, Winnifred Fallers Sullivan, Yunus Doğan Tellie, Hylton White, and Amiel Melnick. I was fortunate to have the opportunity to present this paper to the Seminario en Latinoamérica de Teoría Constitucional y Política in Santiago, Chile, in June 2010. Noah Novogrodsky, Jaya RamjiNogales, and Claire Priest provided particularly detailed comments. And I am grateful to Joseph Slaughter, Samuel Moyn, and Nils Gilman for their many editorial suggestions.

I. Prosecutor v. Dusko Tadic, Decision on the Defense Motion for Interlocutory Appeal on Jurisdiction, para. Io, International Criminal Tribunal for the Former Yugoslavia, Appeals Chamber, October 2, 1995, http://www.icty.org/x/cases/tadic/acdec/en/51002.htm (last accessed October 5 , 20I0).

2. For discussion of recent themes in the United States, see José A. Cabranes, "Our Imperial Criminal Procedure: Problems in the Extraterritorial Application of U.S. Constitutional Law," Yale Law Journal II8 (June 2009): I660-7II.

3. Cicero famously urged that the pirate is "not included in the number of lawful enemies, but is the common foe of all the world; and with him there ought not to be any pledged word nor any oath mutually binding." Cited in Richard Tuck, The Rights of War and Peace: Political Thought and the International Order from Grotius to Kant (New York: Oxford University Press, 1999), 40.

4. Joseph Slaughter, email to author, July 2I, 2010.

5. Bernard H. Oxman, "The Territorial Temptation: A Siren Song at Sea," American Journal of International Law I00 (2006): 830-51, 840; Philip E. Steinberg, The Social Construction of the Ocean (New York: Cambridge University Press, 200I), I69-76. 
6. See Anne L. Clunan, "Ungoverned Spaces? The Need for Reevaluation," in Ungoverned Spaces: Alternatives to State Authority in an Era of Softened Sovereignty, ed. Anne L. Clunan and Harold A. Trinkunas (Stanford: Stanford University Press, 20I0), 4-7. While we perhaps remember Hugo Grotius more for his notion of the free seas, we should not forget the other half of his conceptualization, what we might call the free land. Richard Tuck describes Grotius's claim that the "alleged owners of a territory" "must allow anyone to possess things which are of no use to the owners." Tuck writes that Grotius "perceived that if the sea could not be owned by the men who hunted on it, neither presumably could the land." The land, in local hands, was a wasteland-like a sea. And any local leader who does not see the matter this way, Grotius writes, having "violated a law of nature" "may be punished by war made against them." Our analogy between land and sea with respect to Kenyan sovereignty on land, then, is not far-fetched-it simply repeats a core colonial idea. Tuck, Rights of War and Peace, I04, I06.

7. See also Daniel Heller-Roazen The Enemy of All: Piracy and the Law of Nations (New York: Zone Books, 2009), 179-80.

8. Paul W. Kahn, “On Pinochet," Boston Review (February/March, 1999), http://boston review.net/BR24.I/kahn.html (last accessed October 5, 20I0).

9. United Nations Charter, Article 2(I): "The Organization is based on the principle of the sovereign equality of all its Members."

Io. Makau wa Mutua, "Justice under Siege: The Rule of Law and Judicial Subservience in Kenya," Human Rights Quarterly 23, no. I (200I): 96-II8, 97. Mutua urges: "In spite of the liberal Constitution, the post-colonial state was autocratic at its inception because it wholly inherited the laws, culture, and practices of the colonial state." See also John L. Comaroff and Jean Comaroff, "Law and Disorder in the Postcolony: An Introduction," in Law and Disorder in the Postcolony, ed. Comaroff and Comaroff (Chicago: University of Chicago Press, 2006), I.

II. See Nic Cheeseman, "Introduction: Political Linkage and Political Space in the Era of Decolonization," Africa Today (2006): 3-24; Mahmood Mamdani, Citizen and Subject: Contemporary Africa and the Legacy of Late Colonialism (Princeton: Princeton University Press, 1996); John L. Comaroff, "Reflections on the Colonial State, in South Africa and Elsewhere: Factions, Fragments, Facts and Fictions," Social Identities 4, no. 3 (1998): 32I-6I.

I2. Robert H. Jackson, Quasi-States: Sovereignty, International Relations, and the Third World (New York: Cambridge University Press, 1990), 6r. For a critique that Jackson anachronistically interprets decolonization through the lens of the post-Cold War period and thereby misinterprets independence movements and the Cold War era, see Christopher J. Bickerton, "State Building: Exporting State Failure," in Politics without Sovereignty: A Critique of Contemporary International Relations, ed. Bickerton, Philip Cunliffe, and Alexander Gourevitch (New York: Cambridge University Press, 2007), 93-II2, IO3.

13. Prosecutor v. Dusko Tadic, para. 97.

I4. Peter Borschberg, "Hugo Grotius, East India Trade and the King of Johor," Journal of Southeast Asian Studies 30, no. 2 (1999): 225-48.

I5. Stefan Elköf, Pirates in Paradise: A Modern History of Southeast Asia's Maritime Marauders (Copenhagen: NIAS, 2006), 7.

16. For discussion of shifting lines between raiding and piracy in Southeast Asia with the rise of the colonial state, see James Frances Warren, Iranun and Balangingi: Globalization, Maritime Raiding and the Birth of Ethnicity (Singapore: Singapore University Press, 2002), 4I4; see also 
Esther Velthoen, "Sailing in Dangerous Waters: Piracy and Raiding in Historical Context," IIAS Newsletter (March 2005): 36.

17. Alfred P. Rubin, Law of Piracy, 2nd ed. (Newport, R.I.: Naval War College Press, 1998), I9-2I, 26-30.

18. Ibid., I49, 203.

19. James G. Lydon, Pirates, Privateers and Profits (Upper Saddle River, N.J.: Gregg Press, 1970), 260. The pirate's alter ego, the privateer, remained in service until 1856, when, through the Treaty of Paris, European nations (but not the United States) repudiated the privateer as well. See also Nicholas Parillo, "The De-privatization of American Warfare: How the U.S. Government Used, Regulated, and Ultimately Abandoned Privateering in the Nineteenth Century," Yale Journal of Law and the Humanities i9 (2007): I, 5.

20. Marcus Rediker, "The Pirate and the Gallows," in Seascapes: Maritime Histories, Littoral Cultures, and Transoceanic Exchanges, ed. Jerry Bentley, Renate Bridenthal, and Kären Wigen (Honolulu: University of Hawai'i Press, 2007), 243, 244.

2I. On the breakdown of this modernist narrative with the outsourcing of things like military work, see Mateo Taussig-Rubbo, "Outsourcing Sacrifice: The Labor of Private Military Contractors," Yale Journal of Law and the Humanities 2I (2009): 103-69.

22. For discussion of license selling as "protection racket," see Report of the Monitoring Group on Somalia Pursuant to Security Council Resolution I8II (2008), S/2008/769, (2008), I5, http:// daccess-dds-ny.un.org/doc/UNDOC/GEN/No8/604/73/PDF/No860473.pdf (last accessed October 5 , 2010).

23. "Somali Piracy Backed by International Network," MSNBC.com, December I, 2008, Associated Press, http://www.msnbc.msn.com/id/28158455 (last accessed October 5, 2010); Annex III, UN Report of the Monitoring Group on Somalia Pursuant to Security Council Resolution I853 (2008), S/2010/9I (2010), 99, http://daccess-dds-ny.un.org/doc/UNDOC/GEN/Nio/246/89/PDF/ Nio2468 9.pdf (hereinafter "UN Monitoring Group (2010)") (last accessed October 5, 20IO).

24. UN Monitoring Group (2010), 97-98.

25. "Ships Held by Somali Pirates-FACTBOX," Reuters, May I4, 20I0, http://www.forexy ard.com/en/news/Ships-held-by-Somali-pirates-2010-05-I4T083604Z-FACTBOX (last accessed October 5, 20I0); Scott Baldauff, "Somali Pirates Fight over Record Ransom," Christian Science Monitor, January I8, 20I0. The ransom for less august vessels—a Yemeni fishing vessel or an Indian dhow-is presumably far less.

26. UN Monitoring Group (2010), 37.

27. Mark Bradbury, Becoming Somaliland (Nairobi: E.A.E.P., 2008).

28. "Somalia: Puntland's Leader Says UN Report is 'Politically Motivated,'” Garowe Online, March 22, 20I0, http://www.garoweonline.com/artman2/publish/Somalia_27/Somalia_Puntland_ s_leader_says_UN_report_is_politically_motivated.shtml (last accessed October 5, 20IO). See UN Monitoring Group (2010), 39.

29. Report of the Monitoring Group on Somalia Pursuant to Security Council Resolution 1676 (2006) S/2006/913, (2006) 39-40, http://daccess-dds-ny.un.org/doc/UNDOC/GEN/No6/627/40/ PDF/No66274 O.pdf?OpenElement (last accessed October 5, 20I0).

30. UN Monitoring Group (2010), 37.

31. Alisha Ryu, "Somali Pirates Flee Possible al-Shabab Attack," Voice of America, April 26, 20IO, http://wwwi.voanews.com/english/news/africa/Somali-Pirates-Flee-Possible-al-ShababAttack-92099944.html (last accessed October 5, 2010). 
32. United Nations Security Council Resolution I85I, 6 ("States and regional organizations cooperating in the fight against piracy and armed robbery at sea off the coast of Somalia for which advance notification has been provided by the TFG to the Secretary-General may undertake all necessary measures that are appropriate in Somalia, for the purpose of suppressing acts of piracy and armed robbery at sea, pursuant to the request of the TFG"). For discussion of significance of acting under Chapter VII, see Kim Lane Scheppele, "The Migration of Anti-Constitutional Ideas: The Post-9/II Globalization of Public Law and the International State of Emergency," in The Migration of Constitutional Ideas, ed. Sujit Choudhry (New York: Cambridge University Press, 2007), 347. On the internationally recognized government in Somalia, see Kirsti Samuels, "Constitution-Building during the War on Terror: The Challenge of Somalia," International Journal of Law and Politics 40 (2008): 597-6r4.

33. For discussion of challengers to TFG in Somalia, see UN Monitoring Group (2010), I8-34.

34. The UN Convention on the Law of the Sea provides in Art. 9I that: "Every state shall fix the conditions for the grant of its nationality to ships, for the registration of ships in its territory, and for the right to fly its flag. Ships have the nationality of the state whose flag they are entitled to fly. There must exist a genuine link between the state and the ship." In Art. 94, it provides: "Every State shall effectively exercise its jurisdiction and control in administrative, technical and social matters over ships flying its flag."

35. Containerization and mechanization have significantly reduced the number of crew, presumably making vessels more vulnerable. A "very large crude carrier," a ship a quarter of mile long, can operate with just over twenty crew.

36. UN Convention Against Torture and Other Cruel, Inhuman or Degrading Treatment or Punishment, Art. 3(I). Article 3 prohibits a signatory from expelling, returning, or extraditing "a person to another State where there are substantial grounds for believing that he would be in danger of being subjected to torture." See, for example, Nicholas Kulish, "Legal Hurdles in West Slow Pursuit of Pirates," New York Times, November 28, 2009.

37. See Heller-Roazen, The Enemy of All, in6; see also Eugene Kontorovich, "'A Guantanamo on the Sea': The Difficulties of Prosecuting Pirates and Terrorists, California Law Review 98 (February 2010): 243-76.

38. Cited in Tuck, War and Peace, 162.

39. Douglas Guilfoyle and Andrew Murdoch, "The Use of Lethal Force in Counter-Piracy Operations off Somalia" (forthcoming).

40. This approach received a boost with the approval of a Russian-sponsored UN Security Council Resolution requesting the secretary general to report on "options for creating special domestic chambers possibly with international components, a regional tribunal or an international tribunal and corresponding imprisonment arrangements." UN Security Council Resolution I918 (2010), para. 4 .

4I. See Pauline Jelinek, “Admiral: U.S. Should Pursue Pirate Ransoms," Associated Press, April I6, 20IO, http://www.navytimes.com/news/20Io/o4/ap_navy_fitzgerald_0416Io/ (last accessed October 5, 2010).

42. James R. Brennan, "Lowering the Sultan's Flag: Sovereignty and Decolonization in Coastal Kenya," Comparative Studies in Society and History 50, no. 4 (2008): 83I-6I. Settled over a millennium ago, not long after the advent of Islam, Mombasa is Kenya's main port but is quite marginal in Kenya's centralized political order, especially in relation to the inland capital, Nairobi. The predominantly Muslim and oftentimes Arab traders of the coast long mediated between the 
Middle East and the interior, supplying slaves and goods from inland. In 1730 the city became part of the domain of the Sultan of Zanzibar and was leased to the British. It only became part of Kenya at independence in 1963.

43. Republic v. Hassan Mohamud Ahmed [et. al.], Chief Magistrate's Court at Mombasa, Criminal Case No. 434 (2006), 155.

44. Piracy is defined in the Convention on the High Seas (HSC) (1958), Art. 15, and in the UN Convention on the Law of the Sea (UNCLOS) (1982), Art. IOI. "More or less" because Kenya includes attacks in territorial waters in its definition of piracy. Section 69 of the Penal Code (Chapter 63 of the Laws of Kenya). Kenya and Somalia ratified UNCLOS in 1989. The United States has not ratified the Convention although it recognizes it as expressing customary law (as it did in its Memorandum of Understanding [MOU] with Kenya).

45. Hassan M. Ahmed v. Republic, Crim. App. No. 198, May 12, 2009, High Court of Kenya at Mombasa. One scholar has questioned whether the courts hearing the pirate cases, Kenya's lowest courts, the Magistrate's courts, actually are empowered to exercise extraterritorial jurisdiction, as he finds no grant of original jurisdiction in the constitution and no statutory basis for the exercise. James Thuo Gathii, "Jurisdiction to Prosecute Non-National Pirates Captured by Third States under Kenyan and International Law," Loyola of Los Angeles International and Comparative Law Review (forthcoming).

46. The International Law Commission Commentary on the same provision in the 1958 Convention (which the United States has ratified) rejects the idea of transfer. "This article gives any State the right to seize pirate ships (and ships seized by pirates) and to have them adjudicated upon by its courts. This right cannot be exercised at a place under the jurisdiction of another State" (Art. 43). Yearbook of the International Law Commission, 2 vols. (New York, 1956): 2: 283. But see J. Ashley Roach, "Countering Piracy off Somalia: International Law and International Institutions," American Journal of International Law (2010): 397-416, 405.

47. Catharine Houreld, "Warships Fill Up with Pirates after Kenya Balks," Associated Press, April I5, 20IO, http://abcnews.go.com/International/wirestory?id = I0384342\&page; eqI (last accessed October 5, 2010).

48. Kenya signed agreements with the United States, the United Kingdom, the European Union, Canada, China, and Denmark. In the U.S. MOU, Kenya agrees to "accept custody of and finish appropriate storage of the remains of any person deceased as a result of or incident to a covered act [i.e., piracy or armed robbery against ships]." Kenyan ports and airspace are also to be accessible to U.S. warships, planes, and military personnel engaging in counterpiracy. Provision is made for "technical support, expertise, training and other assistance." See "Memorandum of Understanding between the United States of American and the Republic of Kenya concerning the Conditions of Transfer of Suspected Pirates and Armed Robbers and Seized Property in the Western Indian Ocean, the Gulf of Aden, and the Red Sea" (signed, Washington, DC, January I6, 2009). The EU agreement covers much of the same ground but is more emphatic and detailed regarding the process to which pirates will be subject. See "Exchange of Letters between the European Union and the Government of Kenya," Official Journal of the European Union (March 6, 2009). For discussion of U.S. use of MOUs and other nontreaty instruments, see Oona Hathaway, "Treaties' End: The Past, Present, and Future of International Lawmaking in the United States," Yale Law Journal II7 (2008): I236-372, I249.

49. United Nations Charter, Article 2(I).

50. "Paris-Based Group Says Accused Somali Pirates Denied Rights," Voice of America, 
August 27, 2009, http://www.voanews.com/english/news/a-I3-2009-08-27-voa36-68754822.html (last accessed October 5, 20I0).

51. For discussion of the significance of the quality of Kenyan prison conditions and judicial processes for states subject to the European Convention on Human Rights to transfer pirates to Kenya, see Douglas Guilfoyle, "Counter-Piracy Law Enforcement and Human Rights," International and Comparative Law Quarterly 59 (January 2010): I4I-69, I63-67.

52. Houreld, "Warships Fill Up with Pirates after Kenya Balks."

53. Walter Menya, "Deal on Piracy Trials Skewed, Say Ministers," Daily Nation, June 26, 20I0, http://www.nation.co.ke/News/-/I056/947196/-/w9h9nu/-/index.html (last accessed October 5, 2010).

54. Fred Mukinda and Alphonce Shiundu, "Kenya Laments Pirates' Burden," Daily Nation, March 30, 20I0, www.nation.co.ke/News/-/I056/889976/-/vrw9dl/-/index.html (last accessed October 5, 20I0). The attorney general told a parliamentary committee on defense and foreign relations that the he had not been "part of the policy determination or decision to enter into memorandum of understanding to prosecute piracy cases, it was all done by the ministry of foreign affairs." "My anxiety," he said, "is that we can't hide under the sun anymore, our cases are taking longer than required." The article continues: "The about-turn on the external obligations to fight piracy and the push by Parliament to flex its muscles in the name of protecting the country's sovereignty comes after the 'baits' used to entice the country into signing the agreements were not delivered."

55. Ibid.

56. Philip Alston had earlier described Wako as the "embodiment in Kenya of the phenomenon of impunity." Statement of February 25, 2009, Office of the High Commissioner for Human Rights, http://www.ohchr.org/EN/NewsEvents/Pages/DisplayNews.aspx?NewsID $=8673 \&$ LangID $=\mathrm{E}$ (last accessed October 5, 2010).

57. "UN: Donors to Spend \$9.3 Million to Prosecute Somali Suspects in Kenya, Seychelles," Associated Press, June I5, 20I0; see also Jasper Fakkert, "Kenya Opens Pirate Court," Epoch Times, June 24, 20I0, www.theepochtimes.com/n2/content/view/38023/ (last accessed October 5, 20I0). In September 20Io, Kenya again announced that it was withdrawing from the pirate transfer program. Jeff Davis, "Kenya Cancels Piracy Trial Deals," Sunday Nation, September 30, 20I0, http://www.nation.co.ke/News/Kenya\%2ocancels\%2opiracy\%2otrial\%2odeals/-/IO56/IO2I740/-/ u7eds2z/-/index.html (last accessed October 5, 2010).

58. "Prosecutor Moreno-Ocampo's Statement," Office of the Prosecutor, Press Conference on Kenya, April I, 20I0, www.icc-cpi.int/NR/exeres/6B5I8FBI-C68F-405A-887C-r9CEACF9ICo5 .htm (last accessed October 5, 20I0).

59. Adam Ashforth, "Ethnic Violence and the Prospects for Democracy in the Aftermath of the 2007 Kenyan Elections," Public Culture 2I, no. I (2009): 9-19, I4; see also Kenya National Commission on Human Rights, On the Brink of the Precipice: A Human Rights Account of Kenya's Post-2007 Election Violence (Nairobi, 2008).

6o. Rome Statute of the International Criminal Court, UN Doc. A/CONE 183/9 (Rome: United Nations, July 17, 1998).

6I. Eugene Kontorovich, “The Piracy Analogy: Modern Universal Jurisdiction's Hollow Foundation," Harvard Journal of International Law 45 (2004): I83-237.

62. Willard B. Cowles, "Universality of Jurisdiction over War Crimes," California Law Review 33 (1945): 177, 194, cited by Michael P. Scharf, “The ICC’s Jurisdiction over the Nationals of Non- 
Party States: A Critique of the U.S. Position," Law and Contemporary Problems 64, no. I (Winter 200I): 83 .

63. For the full version of this account, see Antonina Okuta, "National Legislation for Prosecution of International Crimes in Kenya," Journal of International Criminal Justice 7 (2009): 1063. For further discussion of the difficulty in ensuring that "people at top of the apex of the triangle of criminal responsibility bear the heaviest sanctions," see Kenya National Commission on Human Rights, On the Brink, I52.

64. This inside/outside position is also suggested by the ICC statute, which provides that the court's jurisdiction is "complementary to national criminal jurisdictions." Rome Statute, Art. I.

65. "African Countries Back Away from ICC Withdrawal Demand," Sudan Tribune, June Io, 2009, http://www.sudantribune.com/spip.php?article3r443 (last accessed October 5, 2010).

66. Mutuma Ruteere, "Dilemmas of Crime, Human Rights and the Politics of Mungiki Violence in Kenya" (August 27, 2009), 13, http://papers.ssrn.com/sol3/ papers.cfm?abstract_id $={ }_{1462685}$ (last accessed October 5, 2010).

67. Connie Ngondi-Houghton, "Access to Justice and the Rule of Law in Kenya" (2006), www.undp.org/LegalEmpowerment/reports/National\%20Consultation\%2oReports/Country\%20 Files/15_Kenya/15_3_Access_to_Justice.pdf (last accessed October 5, 20I0).

68. David M. Anderson, "Vigilantes, Violence and the Politics of Public Order in Kenya," African Affairs IOI (2002): 542-43.

69. Statement of February 25, 2009, Office of the High Commissioner for Human Rights.

70. Ruteere, "Dilemmas of Crime, Human Rights and the Politics of Mungiki Violence in Kenya," 13.

7I. John Locke, Two Treatises of Government, ed. Peter Laslett (New York: Cambridge University Press, 1988), chap. 2.7.

72. Adam Ashforth, "Ethnic Violence and the Prospects for Democracy," 9-19, I4. See also Robert Blunt, "Of Money And Elders: Ritual, Proliferation, and Spectacle in Colonial and Postcolonial Kenya," (Ph.D. dissertation, University of Chicago, 2010).

73. In Ashforth's view, it is not obvious that the violence was orchestrated by the state or any organization; rather, an incoming group of politicians took advantage of the violence, riding it into positions of more secure authority. For a similar reading, see John Githongo, "Fear and Loathing in Nairobi: The Challenge of Reconciliation in Kenya," Foreign Affairs 89, no. 4 (July/ August 20IO): 6 .

74. Rome Statute, 7(2)(a).

75. International Criminal Court, Pre-Trial Chamber II, "Situation in the Republic of Kenya" (March 31, 20IO), 79 (Kaul, dissenting).

76. Ibid., 80

77. Kenya National Commission on Human Rights, On the Brink, 156-57. The commission found that it would be difficult to "prove that [the violence] was part of a state or organizational policy." It did find, however, that under customary international law the "presence of a policy to commit crimes against humanity does not have to be formalised in a manner directly attributable to a state" and that, under this more forgiving standard, crimes against humanity had taken place.

78. ICC, "Situation in the Republic of Kenya," 49.

79. David Luban, “A Theory of Crimes against Humanity," Yale Journal of International Law 29 (2004): 92.

8o. Ibid. 
8I. Mutahi Ngunyi, "Madaraka Day address to Kibaki and Raila," May 30, 2009, Daily Nation, http://www.nation.co.ke/oped/Opinion/-/440808/604780/-/item/o/-/m i4r47z/-/index .html (last accessed November 22, 20I0).

82. Lauren Benton, "Legal Spaces of Empire: Piracy and the Origins of Ocean Regionalism," Comparative Studies in Society and History 47, no. 4 (October 2005): 700. 